\title{
AN ECONOMETRIC ANALYSIS OF THE IMPACT OF DEMOCRATISATION ON DOMESTIC SAVINGS AND INVESTMENT IN NIGERIA
}

\author{
Godson Dinneya
}

Nigerian Institute of International Affairs

\begin{abstract}
This study employs four-dimensional and one composite indices of democratisation constructed to capture the democratisation processes in Nigeria's transition polity, to investigate the empirical relationships between the levels of democratisation in Nigeria and two economic growth variables - domestic savings and domestic investment. As would be expected, the findings do not settle the debate in any direction. However, they could shed some light on the differences between the dimensional and the overall effects of democratisation on economic variables. The results of the analyses show that the short-run responses of growth variables to changes in democratisation may differ from their long-run responses.
\end{abstract}

JEL E21, 22

\section{1 \\ Introduction}

Abysmally low growth rates in third-world economies are widely attributed to low and declining rates of domestic savings and investment. Recourse to external capital is said to have depressed domestic private savings and investment by frustrating the emergence of an indigenous entrepreneurial class. Recent analyses in many of these poor countries, as outlined in section two below, tend to blame political conditions for the poor performance of these countries' economies. In other words, the presence of an inherent negative relationship between external resources and a country's domestic capacity for growth and development may depend largely on the democratic nature of the economy in question. This concern highlights some key questions in the study of capitalist economic growth, namely which political institutions are most friendly to economic freedoms and under what type of political regime are savers, investors, consumers and producers likely to feel most safe? There appear to be no conclusive answers to these important questions. A reasonable deduction from empirical studies suggests that previous research may have asked the wrong questions. Rather than address the potential correlates of growth, undue attention has been paid to general and complex concepts of growth and development.

This paper attempts to investigate the relationship between levels of democratisation in the political system in Nigeria and rate of domestic savings and investment. ${ }^{1} \mathrm{~A}$ major imperative for this kind of investigation is determining an appropriate measure of democratisation. Nigeria was chosen for this study because of two main factors: 1) low rates of economic growth are still one the major causes of underdevelopment in all poor countries, a category to which Nigeria belongs; and 2) Nigeria's economic problems have been blamed largely on mismanagement of both local and foreign resources by regimes whose democratic nature has been seriously questioned. This paper is organised as follows: section 2 reviews the literature on the relationship between growth and political systems; section 3 summarises the construction of measures of democratisation for Nigeria; section 4 outlines the politimetrics methodology; section 5 presents and discusses the findings; and section 6 gives a conclusion. 


\section{2}

\section{Political systems and economic growth}

Goldsmith (1995: 157-174) aptly captures an age-old controversy by grouping scholars into two camps, the "pessimists" and the "optimists". The pessimist argues that: a) democratic politics leads to increasing demand for welfare spending to the detriment of savings, investment and capital formation, thus impeding growth; b) there is a trade off between popular government and economic development, therefore both are incompatible; c) since poor countries cannot simultaneously pursue democracy and growth with their low national income, authoritarianism serves them better in the early stages of development; d) tough regimes do a superior job of bringing order to society and lay a firmer foundation than democracy can for material improvement; and e) premature efforts to democratise boomerang, for they invite political instability that drive away investment (Goldsmith, 1995: 157-158). The optimists, on the other hand, argue that democracy and capitalism are identical, and therefore that democracy engenders economic progress. Democratic institutions encourage private investment by -

bolstering belief in the political system's durability; they nurture a climate of open debate that is helpful for the efficient allocation of resources; rather than clashing with a competitive economic system, therefore, a competitive polity is imperative for it. Both democracy and capitalism foster freedom of choice and tend to unleash peoples' creative energy. What never work in the long term are authoritarian campaigns to drive forward in a forced march to modernisation (Goldsmith, 1995: 159-160).

To date there appears to be no end to this theoretical debate. Empirical studies also do not provide conclusive evidence of the superiority of one camp over the other. A total of 27 studies on the effects of regime type on economic growth, spanning a period of over 50 years, are reported by Przeworski and Limongi (1993: 58-64), and
Sirowy and Inkeles (1990: 126-157). Of these, five studies ${ }^{2}$ report that authoritarian regimes grow faster than democracies; ten studies ${ }^{3}$ conclude that democracies do better, while five studies report no relationship between the democratic character of regimes and the pace of economic growth. Each of the remaining seven studies produce qualified findings. For example, Adelman and Morris (1967) conclude that democracies grow faster in the medium income bracket, but slower in the low income bracket, while authoritarian regimes grow faster if poor, but slower if low income. Weede (1983: 37-38) finds no difference among various developing countries but suggests that authoritarian regimes grow faster among developing than among developed countries.

Mbaku's study, (1994: 19-22), which is later than Przeworski and Limongi's (1993) review, finds that "democracies do better when economic development, but not growth, is the variable". Mbaku's finding reopens the contentious issue of whether development can take place without prior improvement in growth. It may well be that development-induced wider income distribution is associated more with democratic institutions than authoritarian regimes. To place Mbaku's finding within the optimist domain, the divide between growth and development must be made as narrow as possible. Certainly variables that promote development, such as indices of access to education, health, housing etc. are also growth-enhancing.

What could be responsible for the inconclusiveness of these findings? As would be expected, research methodology is the most frequent culprit. When discussing further research, virtually every new study criticises previous studies' methodology, raising issues of specification problems with the various models used. Sorenson (1998: 69) reviews the almost overwhelming methodological problems associated with empirical studies and argues that, even if these problems can be solved, it will still be "impossible to arrive at a law-like statement concerning the effects of regime type on economic development", because there are so many different types of democratic and authoritarian systems and "we should study outcomes in only comparable pairs of democratic and authoritarian cases". 
Sirowy and Inkeles investigate several relevant questions, including whether any definite patterns can be found between these findings and the period covered in the analysis, the set of countries sampled or the techniques used by researchers. They find no evidence that the findings have any kind of time, space or methodological bias (1990: 148-150). Similarly, Przeworski and Limongi in their conclusion say, "we do not know whether democracy fosters or hinders economic growth", mainly because "we know little about determinants of growth in general" (1993: 64).

These last two conclusions are very instructive in two important ways. First, Przeworski and Limongi's conclusions suggest strongly that, rather than investigate the relationship between the political system and the general concept of growth, attention should be paid to the links between, for example, democratisation and known conventional individual determinants of growth. Two such determinants of growth are domestic savings and domestic investment. Second, Sorenson's conclusion suggests that measuring progress in the development of a political system must take cognisance of peculiarities in the conditions of that environment. These considerations influenced this study's process of finding an appropriate measure of democratisation for the polity under study, as done in a recent study ${ }^{4}$, and summarised in the next section.

\section{3}

\section{Indices of democratisation for Nigeria}

The democracy-development relationship and the importance of incorporating variables that reflect political institutions into any analysis of national growth and development raise the issue of conceptualisation and measurement of such institutional variables. While orthodox economic indicators are quantifiable and therefore easy to measure, political institutional variables present some difficulty. For instance, how should democracy be defined and measured? What institutions provide the framework for sustainable national development? Are existing measures of democratic development suitable for universal application? Since the peoples of the earth are exposed to vastly varying cultural, social, economic, political, psychological and geographic-historical experiences, it is surely commonsense that, despite a common universally accepted body of basic human rights, the process of democratisation will exhibit these differences.

The most widely used quantitative measures of democracy are Raymond Gastil's Index of political freedoms and civil liberties (Gastil, 1999: 26-32). Other equally valid existing measures (e.g. Vanhanen, 1997; Hadenius, 1999) either summarise only one period or decade, or cover only a small number of countries, not including Nigeria. Bollen uses comparative confirmatory factor analysis, a method which tests for random or systematic measurement errors in variables, and concludes, "The variables with the highest validity are Gastil's political rights" (1993: 1219). The popularity of Gastil's measure is further demonstrated by Goldsmith's (1995: 163) account of a record 35 citations in the 1990 edition of the Social Science Citation Index.

With all its credentials and availability as a continuous measure of levels of democracy, the Gastil Index has been found to suffer from very low variability especially when applied to societies in transition; Federkke, De Kadt and Luiz argue that a measurable relationship between two indicators requires that there be variation in both (2001: 103-134). Federkke et al.'s criticism reinforces earlier dissatisfaction with the Gastil Index. According to Sklar, "despite the preponderance of evidence of an oscillating political development in Nigeria since its independence, and in many other African countries evaluated by the Gastil Index, the measure remained static, assigning virtually same level of ranking for several consecutive years" (1987; 1995: 26-28). Nigeria's ranking on the Gastil Index reflects these criticisms. From 1972 when the Index was first constructed to 1979 the rankings for both political freedom and civil liberty remained steady at "partly free", and between 1979 and 1984 stationary at "free". Another stationary state followed for three years. Variation in the ranking did not improve until 1998. 
The lack of variability in the Gastil Index is a direct consequence of the measure as a product, devoid of its own processes. Obviously, despite the procedural claim of detailed coverage of numerous dimensions of democratisation, the ranking actually places undue emphasis on elections, for only in the periods where elections took place does the Index show any sign of movement from its customary steady state. Outside election years, transition societies characterised by oscillating political development are ranked very poorly. This nearzero performance on orthodox democracy scales such as the Gastil Index has given empirical support for and further impetus to the idea that democracy is not feasible in poor African countries. Championed by Polish political economist Andréski since 1968, the list of protagonists has grown to include, among others, Larry Diamond and David Kaplan ${ }^{5}$.

Andréski's original hypothesis is that "democracy is compatible with rapid economic growth only in countries which already have enough resources to make heavy investment in a relatively painless process... There is no case of a democratic government breaking through a vicious circle of misery and parasitism" (Andréski, 1968: 266). Here political freedom is viewed as a luxury good whose high income-elasticity ensures the emergence of democratisation only at high levels of per capita income.

Among the first notable opposition to this infeasibility thesis, and one which rekindled interest in African democracy, was Richard Sklar's. He sees enormous potential for Africa as a "workshop of democracy" and advocates developmental democracy (Sklar, 1986: 696). Another powerful voice is Ake's, who says of the incompatibility between democracy and development: "the primary issue [is] not whether it is more important to eat well than to vote, but who is entitled to decide which is more important, and once this is understood the argument that democracy must be sacrificed to development collapses" (1991: 39-40). To further disprove the infeasibility thesis, Peterson provides a comprehensive list of ten myths about democracy in Africa, which "though largely false, [have] already become objects of worship, misleading and influencing African history"
(1994: 139). He argues that democracy in Africa is real, with enormous potential, and that its consolidation requires that setbacks, like poor governance, corrupt leadership, absence of the rule of law and closed authoritarianism, around which the myths are built be seen as a challenge that must be survived.

Despite these vigorous challenges to the theoretical foundations of the infeasibility thesis, the ratings assigned to African transition societies by existing measures of democracy derive their validity from this thesis, which treats democracy as a product only, and relegates the processes which bring about the end product. Under existing (product) measures, "transition societies" present a special case of nations, where despite continuing attempts and struggles aimed at achieving higher national developments, neither the general level of national development nor the desired actual specific political freedoms have been achieved.

Sklar's (1986) description of Africa as a workshop of democracy emphasises democratic processes, albeit at the theoretical level. The infeasibility fallacy needs to be addressed from an empirical perspective, by looking at democratisation in transition political economies as a process of institutional reforms (when deliberate) or evolution (when voluntary) that move in either direction, between the two utopian poles that may be termed "absolute democracy" and "total authoritarianism". As noted by Sorenson, "a macro framework of democracy does not guarantee its reality on the local level; while its authoritarian counterpart does not completely block democratic elements on the local level" (1995: 399). With this definition, there is bound to be some degree of democracy in the character of political leadership of even the worst of authoritarian regimes. Sklar captures the point when he notes that all political systems have (and ought to have) both democratic and oligarchic components, and that effective governance in so-called democracies is often achieved by oligarchic components acceptable to all major political stakeholders (1995: 26-27). For Africa, therefore, what should be more important as a concept is not democracy per se but the dynamic processes that move political systems towards or away from the ideal of democratisation. 
A process approach to evaluating democracy has both domestic and international policy implications. Locally, it offers hope even in the face of frustrating and apparently unyielding democratic dividends; it is also perhaps the only way to qualify countries such as Nigeria as a democratising state, thereby removing the blocks to such benefits as the international community currently attaches to democratising states. Should the international community decide to advocate the process approach, international perceptions of human rights and other allied business and environmental ratings of many transition political economies in Africa will improve; the highly indebted poor countries of sub-Saharan Africa, in particular, stand to benefit from an expanded classification.

A meaningful measure of democratisation in societies such as Nigeria, where the level of actual political freedom have been low despite continuing struggles to instate democracy, should move beyond the "snapshot approach" and capture major occurrences in the course of the process. Exclusive emphasis on the end product of actual freedoms enjoyed by citizens misses the point and value of those freedoms, and denies their foundations and the beneficial implications of learning from past experiences. Such undue emphasis on actual freedoms underplays the foundations that democratic struggles lay for political development in the future.

Measuring democracy in transition societies, such as Nigeria, should for obvious practical purposes downplay the importance of the actual levels of political freedoms by emphasising the processes, without entirely ignoring the product of democratisation. Dinneya and Tsegaye (2004) argue that to identify the relevant dimensions of democratisation in Nigeria, we first have to assume that the natural rights of Nigerian citizens are their sole input to the political process. The democratisation process in a typical transition polity revolves around four main dimensions. The first is political input in the form of the electoral and "selectoral" processes by which political power is achieved and maintained by political stakeholders. Electoral processes arise from a wider distribution of natural rights while selectoral processes from a concentration of rights. In other words, electoral processes become more widespread the more democratic the political system, and selectoral processes more widespread the less democratic the system. Both elections and selections express the investment of rights and delegation of authority, to the "elect" and "select" respectively.

The second level involves governance as management of citizens' investible rights, the responsibility of which is shared among the executive, legislative and judicial arms of a polity. These responsibilities become more separated the more democratic the system is, and less separated the less democratic the system is. The political environment, the third level, represents the intermediate output produced by the interaction of electoral and selectoral processes and the nature and quality of governance. It acts as input to the next level. As with any investment, the fourth level consists not only of the actual rights and liberties that can be enjoyed by citizens but also the expectation of future rights that will enable them to make input to the next round of the process. Every political system goes through these processes irrespective of whether the dominant regimes are militarycivil diarchy, military-personal dictatorship or democratic civilian.

This understanding of political process leads to four measurable primary indices of democratisation, which can be used to measure democracy in Nigeria; these are power change, quality of governance, political environment, and democratic dividends ${ }^{6}$.

The democratic content of power change (GINC) is given by formula 1.1:

$$
\begin{aligned}
& G I N C=E L+S L \\
& E L=R G L+I N C+O P N+F A I \\
& S L=P E C+V L T
\end{aligned}
$$

Substituting equations 1.2 , and 1.3 into equation 1.1 gives formula 1.4:

$$
\begin{aligned}
G I N C= & R G L+I N C+O P N+F A I+ \\
& P E C-V L T
\end{aligned}
$$

Where EL = election, measured by the degree of its regularity (RGL), inclusiveness (INC), openness (OPN) and fairness (FAI), and SL = selection, measured by peacefulness (PEC) and its level of violence (VLT). 
The democratic content of governance (QIG) is given by formula 2.1:

$$
\begin{aligned}
& Q I G=E Q+L Q+J Q \\
& E Q=O C T+C P T \\
& L Q=L I P+L F T \\
& J Q=C S P+J I P
\end{aligned}
$$

Substituting equations 2.2, 2.3, and 2.4 into equation 2.1 gives formula 2.5:

$$
\begin{aligned}
Q I G= & O C T+C P T+L I P+L F T+ \\
& C S P+J I P
\end{aligned}
$$

Where EQ = executive quality, measured by the level of consultation with opposition/major political stakeholders in crucial policy decisionmaking (OCT) and the level of civil participation in executive functions (CPT); LQ = legislative quality, measured by the level of independence of the legislature (LIP) and the functionality of the legislature (LFT); and JQ = judiciary quality, measured by constitutional support (CSP), and judicial independence (JIP).

The democratic content of political environment (PIE) is given by formula 3.1:

$$
\begin{aligned}
& P I E=P S+A S-D S \\
& P S=T A L-T G N \\
& A S=L D R-C S I \\
& D S=O F D+A D S
\end{aligned}
$$

Substituting equations $3.2,3.3$, and 3.4 into 3.1 gives formula 3.6:

$$
\begin{aligned}
P I E= & T A L-T G N+L D R-C S I- \\
& (O F D+A D S)
\end{aligned}
$$

Where PS = level of potential stability measured by the difference between tension alleviation (TAL) and tension generation (TGN); AS = level of actual stability, assessed by the gap between the level of law and order (LDR) and the level of crisis and instability (CSI); and DS $=$ level of democratic struggle, indicated by the existence and quantity of organisational framework for democratic struggle (OFD) and the intensity of actual democratic struggle (ADS).
The level of democratic dividends (PID) is given by formula 4.1:

$$
\begin{aligned}
& P I D=L B+D H \\
& L B=O F D+I F D \\
& D H=P M T+C M T
\end{aligned}
$$

Substituting equations 4.2 and 4.3 into equation 4.1 gives formula 4.4:

$P I D=O F D+I F D+P M T+C M T$

Where LB = level of liberty enjoyed by citizens, measured by the levels to which organisational freedom (OFD) and individual freedoms (IFD) are allowed; $\mathrm{DH}=$ democratic hope, measured by government pronouncements (PMT) and the government's actual commitment (CMT) to democratic principles.

In addition, a composite index, the democratisation index for Nigeria (DIN), is obtained by a simple average of the scores of the indices GINC, QIG, PIE and PID. In this case, democratic variables complement one another, in recognition that the various dimensions of democratisation are complementary. In all cases, the higher the score for the index, the more democratic the system can be taken to be.

The democratisation index for Nigeria (DIN) is given by formula 5 :

$D I N=G I N C+Q I G+P I E+P I D$

Where GINC, QIG, PIE, and PID measure democratic content and quality of power change, governance, political environment and democratic dividends respectively.

\section{4}

\section{Methodology and data}

\subsection{Data generation}

The scores calculated using equations 1.4, 2.5, 3.6, 4.4, and 5 are presented in Table 1 . In addition to this primary data, secondary data on state creation in Nigeria, revenue allocation formulae and industrial unrest in Nigeria constitute part of the input for the construction of the democratisation indices. Data for domestic savings and domestic investments and their respective correlates that form the base 
equations are presented in Tables 2.1 and 2.2. All the data are drawn from publications of the Central Bank of Nigeria (CBN), the Federal Ministry of Finance (FMF) and the Federal Office of Statistics (FOS). While FOS is the statutory institution for economic, demographic and financial data generation and publication, the CBN and FMF have joint responsibility for collation and publication of the country's external debt data.
The real variables in the base equations are calculated by deflating nominal values by the implicit price index in 1984/85 constant prices. This period was chosen for convenience sake, since the highest number of data sources is available for $1984 / 85$, and also because this period is the mid-point of the study period.

Table 1

Summary scores for democratisation variables

\begin{tabular}{|c|c|c|c|c|c|c|c|c|c|}
\hline \multirow[t]{2}{*}{ year } & \multicolumn{2}{|c|}{ GINC } & \multicolumn{2}{|c|}{ QIG } & \multicolumn{2}{|c|}{ PIE } & \multicolumn{2}{|c|}{ PID } & \multirow[t]{2}{*}{ DIN } \\
\hline & score & \%score & score & \%score & score & \%score & score & \%score & \\
\hline 1960 & 64.00 & 64.00 & 102.00 & 68.000 & 37.7114 & 37.7114 & 69.00 & 69.00 & 53.830 \\
\hline 1961 & 75.00 & 75.00 & 102.00 & 68.000 & 36.7114 & 36.7114 & 70.00 & 70.00 & 57.080 \\
\hline 1962 & 64.00 & 64.00 & 96.00 & 64.000 & 21.7114 & 21.7114 & 64.00 & 64.00 & 48.080 \\
\hline 1963 & 62.00 & 62.00 & 100.00 & 66.667 & 41.7628 & 41.7628 & 64.00 & 64.00 & 51.760 \\
\hline 1964 & 47.00 & 47.00 & 98.00 & 65.333 & 42.7628 & 42.7628 & 61.00 & 61.00 & 46.680 \\
\hline 1965 & 42.00 & 42.00 & 96.00 & 64.000 & 26.284 & 26.284 & 58.00 & 58.00 & 39.220 \\
\hline 1966 & -5.00 & -5.00 & 52.00 & 34.667 & 2.284 & 2.284 & 31.00 & 31.00 & 9.391 \\
\hline 1967 & -8.00 & -8.00 & 53.00 & 35.333 & 4.53803 & 4.53803 & 24.00 & 24.00 & 9.273 \\
\hline 1968 & -14.00 & -14.00 & 46.00 & 30.667 & 1.53803 & 1.53803 & 24.00 & 24.00 & 7.357 \\
\hline 1969 & -17.00 & -17.00 & 46.00 & 30.667 & 0.25632 & 0.25632 & 24.00 & 24.00 & 6.786 \\
\hline 1970 & 8.00 & 8.00 & 51.00 & 34.000 & 25.9828 & 25.9828 & 42.00 & 42.00 & 24.300 \\
\hline 1971 & 10.00 & 10.00 & 49.00 & 32.667 & 41.3381 & 41.3381 & 42.00 & 42.00 & 26.460 \\
\hline 1972 & 12.00 & 12.00 & 49.00 & 32.667 & 36.3147 & 36.3147 & 45.00 & 45.00 & 26.450 \\
\hline 1973 & 14.00 & 14.00 & 45.00 & 30.000 & 38.3684 & 38.3684 & 46.00 & 46.00 & 26.550 \\
\hline 1974 & 9.00 & 9.00 & 48.00 & 32.000 & 38.1951 & 38.1951 & 37.00 & 37.00 & 22.510 \\
\hline 1975 & 13.00 & 13.00 & 47.00 & 31.333 & 25.3418 & 25.3418 & 44.00 & 44.00 & 21.880 \\
\hline 1976 & 10.00 & 10.00 & 48.00 & 32.000 & 39.1574 & 39.1574 & 48.00 & 48.00 & 25.750 \\
\hline 1977 & 13.00 & 13.00 & 51.00 & 34.000 & 36.9901 & 36.9901 & 50.00 & 50.00 & 26.460 \\
\hline 1978 & 13.00 & 13.00 & 56.00 & 37.333 & 35.7916 & 35.7916 & 56.00 & 56.00 & 28.490 \\
\hline 1979 & 69.00 & 69.00 & 97.00 & 64.667 & 35.1398 & 35.1398 & 60.00 & 60.00 & 50.160 \\
\hline 1980 & 72.00 & 72.00 & 102.00 & 68.000 & 44.1047 & 44.1047 & 70.00 & 70.00 & 55.980 \\
\hline 1981 & 74.00 & 74.00 & 101.00 & 67.333 & 43.8153 & 43.8153 & 65.00 & 65.00 & 54.500 \\
\hline 1982 & 72.00 & 72.00 & 101.00 & 67.333 & 44.8903 & 44.8903 & 64.00 & 64.00 & 54.010 \\
\hline
\end{tabular}




\begin{tabular}{|c|c|c|c|c|c|c|c|c|c|}
\hline 1983 & 42.00 & 42.00 & 99.00 & 66.000 & 40.904 & 40.904 & 63.00 & 63.00 & 44.930 \\
\hline 1984 & 6.00 & 6.00 & 42.00 & 28.000 & 22.6838 & 22.6838 & 32.00 & 32.00 & 16.280 \\
\hline 1985 & 10.00 & 10.00 & 49.00 & 32.667 & 21.6664 & 21.6664 & 32.00 & 32.00 & 18.690 \\
\hline 1986 & 11.00 & 11.00 & 49.00 & 32.667 & 34.2043 & 34.2043 & 32.00 & 32.00 & 19.730 \\
\hline 1987 & 72.00 & 72.00 & 47.00 & 31.333 & 39.5823 & 39.5823 & 38.00 & 38.00 & 36.300 \\
\hline 1988 & 61.00 & 61.00 & 51.00 & 34.000 & 32.7281 & 32.7281 & 39.00 & 39.00 & 31.210 \\
\hline 1989 & 63.00 & 63.00 & 53.00 & 35.333 & 33.1287 & 33.1287 & 41.00 & 41.00 & 31.950 \\
\hline 1990 & 55.00 & 55.00 & 50.00 & 33.333 & 37.1356 & 37.1356 & 42.00 & 42.00 & 27.770 \\
\hline 1991 & 58.00 & 58.00 & 51.00 & 34.000 & 45.2167 & 45.2167 & 42.00 & 42.00 & 28.670 \\
\hline 1992 & 54.00 & 54.00 & 62.00 & 41.333 & 48.6342 & 48.6342 & 38.00 & 38.00 & 27.460 \\
\hline 1993 & 11.00 & 11.00 & 58.00 & 38.667 & 45.0086 & 45.0086 & 26.00 & 26.00 & 9.947 \\
\hline 1994 & 3.00 & 3.00 & 40.00 & 26.667 & 55.7595 & 55.7595 & 17.00 & 17.00 & 3.496 \\
\hline 1995 & 3.00 & 3.00 & 40.00 & 26.667 & 64.1939 & 64.1939 & 17.00 & 17.00 & 4.410 \\
\hline 1996 & 3.00 & 3.00 & 37.00 & 24.667 & 63.0231 & 63.0231 & 18.00 & 18.00 & 3.867 \\
\hline 1997 & 3.00 & 3.00 & 31.00 & 20.667 & 54.0494 & 54.0494 & 16.00 & 16.00 & -0.570 \\
\hline 1998 & 12.00 & 12.00 & 40.00 & 26.667 & 50.3826 & 50.3826 & 48.00 & 48.00 & 10.260 \\
\hline 1999 & 56.00 & 56.00 & 96.00 & 64.000 & 52.3333 & 52.3333 & 58.00 & 58.00 & 36.580 \\
\hline 2000 & 56.00 & 56.00 & 96.00 & 64.000 & 57.3333 & 57.3333 & 58.00 & 58.00 & 39.330 \\
\hline
\end{tabular}

Source: calculated from equations 1.4, 2.5, 3.6 and 5.

\section{Table 2.1}

Domestic savings and its determinants

\begin{tabular}{|c|c|c|c|c|c|}
\hline year & GDS & RGDS & IDS & DSR & RFDI \\
\hline 1970 & 565.000 & 5879.3 & 3.0 & 0.596 & 10439.1 \\
\hline 1971 & 948.100 & 9481.0 & 3.0 & 0.607 & 13228.0 \\
\hline 1972 & 2240.000 & 21538.5 & 3.0 & 0.363 & 15106.7 \\
\hline 1973 & 2820.000 & 18926.2 & 3.0 & 0.280 & 11836.9 \\
\hline 1974 & 5410.000 & 24369.4 & 3.0 & 0.159 & 8162.6 \\
\hline 1975 & 4760.000 & 17662.3 & 3.0 & 0.152 & 8487.9 \\
\hline 1976 & 7370.000 & 23990.9 & 2.7 & 0.126 & 7613.9 \\
\hline 1977 & 10300.000 & 30231.9 & 2.8 & 0.078 & 7430.0 \\
\hline 1978 & 8410.000 & 20765.4 & 4.2 & 0.446 & 7069.6 \\
\hline 1979 & 11940.000 & 25243.1 & 4.5 & 0.424 & 6666.2 \\
\hline 1980 & 16430.000 & 31058.6 & 5.3 & 0.200 & 6843.3 \\
\hline 1981 & 9760.000 & 13555.6 & 5.7 & 1.022 & 5219.3 \\
\hline
\end{tabular}


Table 2.1 Continued

\begin{tabular}{|c|c|c|c|c|c|}
\hline 1982 & 7290.000 & 9904.9 & 7.6 & 1.499 & 7313.6 \\
\hline 1983 & 6190.000 & 7239.8 & 7.4 & 2.337 & 6958.5 \\
\hline 1984 & 7270.000 & 7270.0 & 8.3 & 4.151 & 6418.3 \\
\hline 1985 & 9140.000 & 8788.5 & 9.1 & 5.758 & 6542.3 \\
\hline 1986 & 8520.000 & 8352.9 & 9.2 & 2.694 & 9131.0 \\
\hline 1987 & 19200.000 & 12549.0 & 13.1 & 0.898 & 6531.8 \\
\hline 1988 & 21080.000 & 11272.7 & 13.0 & 1.349 & 6063.7 \\
\hline 1989 & 51890.000 & 19318.7 & 14.7 & 0.781 & 4057.9 \\
\hline 1990 & 84140.000 & 29225.4 & 19.8 & 1.709 & 3624.9 \\
\hline 1991 & 76590.000 & 22394.7 & 14.9 & 1.104 & 3580.0 \\
\hline 1992 & 120240.000 & 21345.6 & 18.0 & 0.523 & 3641.5 \\
\hline 1993 & 99719.110 & 14245.6 & 23.2 & 0.239 & 9541.0 \\
\hline 1994 & 77616.890 & 8605.0 & 13.1 & 0.190 & 7839.8 \\
\hline 1995 & 194106.260 & 10162.6 & 13.5 & 0.082 & 6250.9 \\
\hline 1996 & 209392.200 & 7980.5 & 13.1 & 0.123 & 4672.6 \\
\hline 1997 & 466415.960 & 18162.6 & 7.2 & 0.077 & 4997.3 \\
\hline
\end{tabular}

Source: calculated from Central Bank of Nigeria (CBN) Statistical Bulletin, various years FOS Abstract of Statistics and Federal Ministry of Finance documents.

Table 2.2

Domestic investment and its determinants

\begin{tabular}{|c|c|c|c|c|}
\hline year & GDI & RGDI & CHGDP & DSR \\
\hline 1970 & 973.000 & 10124.870 & 5120.130 & 0.596 \\
\hline 1971 & 1524.500 & 15245.000 & 5120.130 & 0.607 \\
\hline 1972 & 2330.000 & 22403.846 & 7158.846 & 0.280 \\
\hline 1973 & 2750.000 & 18456.376 & -3947.470 & 0.159 \\
\hline 1974 & 3330.000 & 15000.000 & -3456.376 & 0.152 \\
\hline 1975 & 5790.000 & 21484.230 & 6484.230 & 0.126 \\
\hline 1976 & 9010.000 & 29329.427 & 7845.197 & 0.078 \\
\hline 1977 & 9510.000 & 27913.120 & -1416.307 & 0.446 \\
\hline 1978 & 9930.000 & 24518.519 & -3394.602 & 0.424 \\
\hline 1979 & 9480.000 & 20042.283 & -4476.235 & 0.200 \\
\hline 1980 & 11310.000 & 21379.962 & 1337.679 & 1.022 \\
\hline 1981 & 11820.000 & 16416.667 & -4963.296 & 1.499 \\
\hline 1982 & 10390.000 & 14116.848 & -2299.819 & 2.337 \\
\hline 1983 & 8420.000 & 9847.953 & -4268.895 & \\
\hline
\end{tabular}




\begin{tabular}{|c|c|c|c|c|}
\hline 1984 & 6060.000 & 6060.000 & -3787.953 & 4.151 \\
\hline 1985 & 6490.000 & 6240.385 & 180.385 & 5.758 \\
\hline 1986 & 11010.000 & 10794.118 & 4553.733 & 2.694 \\
\hline 1987 & 14910.000 & 9745.098 & -1049.020 & 0.898 \\
\hline 1988 & 19560.000 & 10459.893 & 714.795 & 1.349 \\
\hline 1989 & 32420.000 & 12069.993 & 1610.100 & 0.781 \\
\hline 1990 & 41730.000 & 14494.616 & 2424.624 & 1.709 \\
\hline 1991 & 55190.000 & 16137.427 & 1642.811 & 1.104 \\
\hline 1992 & 96340.000 & 17102.787 & 965.360 & 0.523 \\
\hline 1993 & 80498.070 & 11499.724 & -5603.063 & 0.239 \\
\hline 1994 & 85553.190 & 9484.833 & -2014.892 & 0.190 \\
\hline 1995 & 373201.560 & 19539.349 & 10054.516 & 0.082 \\
\hline 1996 & 174696.540 & 6658.150 & -12881.199 & 0.123 \\
\hline 1997 & 140458.790 & 5469.579 & -1188.571 & 0.077 \\
\hline
\end{tabular}

Source: calculated from Central Bank of Nigeria (CBN) Statistical Bulletin, various years

\subsection{Methodology}

\section{Dependent and independent variables}

As noted above, the dependent variables are domestic savings and domestic investment. Of course, factors other than the democratisation process also influence both domestic savings and investment. Investigating the marginal impact of democratisation therefore involves using a base equation containing the more conventional economic variables. There are therefore two sets of independent variables - control variables and democratisation variables.

The democratisation (independent) variables are the Index of Democratic Dividend (PID), the Index of Political Environment (PIE), the Index of the Quality of Governance (QIC), the Index of Power Change (GINC) and the composite Index of Democratisation for Nigeria (DIN). By using these five explanatory variables of democratisation, this analysis attempts to explore the relative importance of each in the explanation of variations in the dependent variables. While the first four variables capture the possible impacts of the individual dimensions of democratisation on savings and investment, the last variable intends to measure the impact of the overall democratisation process on savings and investment decisions.

\section{Functional forms of the model}

The base equation expresses each dependent variable as a function of theoretically and empirically established conventional variables. It is not feasible to include all the variables used in previous studies, so the traditionally acceptable practice of including those that appear most frequently in previous studies involving the dependent variable in the base equation will be used (Torstensson, 1994: 232-233).

\section{Domestic savings equation}

Other things being equal, domestic savings is expected to grow with growth in disposable income, and with increases in savings interest rate. In the base equation, domestic savings is a positive function of national disposable income and domestic savings interest rate. Foreign direct investment is also included to accommodate the widely discussed "crowdingout" effect on domestic savings.

$$
\begin{aligned}
R G D S= & \alpha+\beta_{0} N D Y+\beta_{I} I D S+\beta_{2} D S R+ \\
& \beta_{3} R F D I+u
\end{aligned}
$$


Where RGDS is real gross domestic savings, NDY is real national disposable income, IDS is rate of interest on domestic savings, DSR is ratio of debt service to GDP, RFDI is real foreign direct investment and $u$ is the stochastic error term. The exogenous savings $(\alpha)$ is expected to be negative, indicating that economic agents will draw from past savings when they earn no additional income; the coefficients $\left(\beta_{0}\right)$ and $\left(\beta_{1}\right)$ are both expected to be positive; and $\left(\beta_{2}\right)$ is expected to be negative. A belief in the crowding-out effect of FDI on domestic savings suggests that the coefficient $\left(\beta_{3}\right)$ will be negative.

\section{Domestic investment equation}

Following Iyoha (2000), the base domestic investment equation is specified as a negative function of the domestic lending rate of interest, but a positive function of the change in GDP. Debt service ratio is also included as an explanatory variable in order to capture the effect of debt burden on domestic investment.

$$
\begin{aligned}
R G D I= & \alpha+\beta_{0} I D L+\beta_{1} C H G D P+ \\
& \beta_{2} D S R+u
\end{aligned}
$$

Where RGDI is real gross domestic investment, IDL is the rate of interest on domestic lending, CHGDP is change in gross domestic product, which is intended to capture the possible existence of an investment accelerator effect, and DSR is debt burden proxied by the ratio of debt service to exports. The expected sign of the autonomous investment $(\alpha)$ is positive. Coefficients $\beta_{0}$ and $\beta_{2}$ are expected to be negative while $\beta_{1}$ is expected to be positive; $u$ is the stochastic error term.

\section{Inclusion of democratisation variables}

To complete the specifications, each of the democratisation variables enters into the base equation linearly as one of the explanatory variables. The linearity assumption in the relationship between institutional and economic variables is as contentious as the main issue of whether any relationships exist in the first place. However, as in Goldsmith (1995: 160164), this study favours linearity. Accordingly, equations 6 and 7 can be reformulated generally as follows:

$$
\begin{aligned}
\mathrm{Y}_{\mathrm{i}}= & \alpha+\beta_{\mathrm{o}} \mathrm{X}_{1}+\beta_{1} \mathrm{X}_{2}+\ldots \beta_{\mathrm{i}} \mathrm{X}_{\mathrm{i}}+ \\
& \varphi_{\mathrm{i} \cdot{ }_{5} \mathrm{Z}_{\mathrm{i}} \cdots{ }_{5}+u \ldots}+
\end{aligned}
$$

Where $\mathrm{Y}_{\mathrm{i}}$ is the dependent variable, $\mathrm{X}_{1}, \mathrm{X}_{2}, \mathrm{X}_{3} \ldots$ $X_{i}$ are the control variables in the base equations, with coefficients $\beta_{\mathrm{o}}, \beta_{1}, \ldots \beta_{\mathrm{i}} ; \mathrm{Z}_{\mathrm{i}}$ represents GINC, QIG, PIE, PID and DIN respectively. $\varphi_{i} \cdots_{5}$ are their respective coefficients.

The expected signs of the coefficients in equation (8) depend on whether democratisation is viewed as having a positive or negative impact on the dependent variables. From an optimist's viewpoint, since democracy is expected to build the confidence of citizens in their government, and since policies that affect incomes are not expected to change arbitrarily, there should be greater optimism with higher democratisation and income earners can be expected to postpone present consumption for savings. Similarly, the investing public will be more confident of a politically stable environment since the risks associated with an unpredictable political and therefore business environment can be expected to be lower in systems that are more democratic.

Domestic savings as well as domestic investments are therefore expected to be positively affected by improvements in the Index of Political Dividend (PID), the Index of Political Environment (PIE), the Index of the Quality of Governance (QIC), the Index of Government Change (GINC) and the composite Index of Democratisation (DIN). The coefficients in the savings and investment equations are therefore expected to be positive.

\section{Estimation techniques $^{7}$}

Regressions are carried out under the AR(1) model using the EVIEWS econometric computerisation tool. This is to eliminate possible serial/autocorrelation errors noticed in preliminary analyses employing OLS technique. EVIEWS estimates AR models using nonlinear regression techniques. This approach has the advantage of being easy to understand, generally applicable and easily extended to nonlinear specifications and models that contain endogenous right-hand side variables. Since nonlinear least squares estimates are asymptotically equivalent to maximum likelihood estimates, they are asymptotically efficient. 
To estimate an AR(1) model, EVIEWS transforms the linear model, $Y_{t}=X_{t} \beta+\mu_{t}$ where $\mu_{t}=\rho \mu_{t-1}+\varepsilon_{t}$, into the non-linear model, $\mathrm{Y}_{\mathrm{t}}=\rho \mathrm{Y}_{\mathrm{t}-1}+\left(\mathrm{X}_{\mathrm{t}}-\rho \mathrm{X}_{\mathrm{t}-1}\right) \beta+\varepsilon_{\mathrm{t}}$.

Substituting the second equation into the first, and then rearranging the terms achieves the transformation. The coefficients $\rho$ and $\beta$ are estimated simultaneously by applying a Marquardt non-linear least squares algorithm to the transformed equation.

A set of statistics that is unique to AR models is the estimated AR parameters $\rho$. For the simple AR(1) model, the estimated parameter is the serial correlation coefficient of the unconditional residuals. For a stationary AR(1) model, the true $\rho$ lies between -1 (extreme negative serial correlation) and +1 (extreme positive serial correlation). The stationarity condition for general $A R(\mathrm{\rho})$ processes is that the inverted roots of the lag polynomial lie inside the unit circle. EVIEWS reports these roots as Inverted AR Roots. There is no particular problem if the roots are imaginary, but a stationary AR model should have all roots with modulus less than one.

The base equation was regressed in its original specification. Where any variable was found to lack statistical significance, that variable was dropped from the model. All variables were transformed into their log forms. By this transformation, the analyses in the log-log equations are interested in the rate of change in the dependent variable due to rates of change in the explanatory variables. In other words, the interpretation of the partial coefficients relates to the impact of changes in the rate at which democratisation is improving, expressed as percentage changes in the mean values of domestic investment and domestic savings.

To find out if the rate of improvement in democratisation is more important in the short term than in the long term, two sets of regression are run, one using current values and the other using real values of the dependent variable.

\section{5 \\ Results and discussion}

\subsection{Results}

The partial regression coefficients and $t$-statistics for domestic savings and domestic investments are presented in tables 3.1-3.4. Column one in each table shows the independent variables with the expected sign of their coefficients in parenthesis. Column two shows the partial regression coefficients of the independent variables of the base equation. Columns three to seven show the partial regression coefficients of the equations including the introduced democratisation variable. The most important statistics are highlighted along the diagonal in each table. The last four rows show the adjusted $\mathrm{R}^{2}$, the F- statistics, the Durbin-Watson (D-W) statistics, and the Inverted AR-Root-serial correlation coefficient of the unconditional residuals.

Although the standard procedure for interpreting multiple regression results is followed, the emphasis is, first, on the signs and statistical significance of the partial regression coefficients relating to the introduced democratisation variables. Emphasis is then put on the observed improvement (or the absence of it) in the adjusted multiple coefficient of determination $R^{2}$ due to the introduction of a democratisation variable. These emphases are informed by the central research question of whether or not each of the democratisation variables is a reliable determinant of domestic savings, and domestic investment, and how much improvement in the explanation of variations is achieved by the introduction of this variable.

\section{Domestic savings and level of democratisation}

In the domestic savings regressions, disposable income does not make any statistically significant contribution to variations in domestic savings and so was dropped. The base equation using current values of domestic savings was therefore run with domestic deposit interest rate (IDS), foreign direct investment (RFDI) and debt service ratio (DSR). The partial coefficients of all three variables are of the expected signs, positive for (IDS) and negative for both (FDI) and (DSR). 
Coefficients for (FDI) and (DSR) are both significant at 1 per cent. Although the coefficient for (IDS) narrowly misses the 10 per cent significance level, it is retained in the base equation because its significance improved in subsequent regressions. Thus in the base regression, foreign direct investment is confirmed to be a drag on domestic savings. The base regression explains 85 per cent of the variation in the current rate of domestic savings for the period.

Introducing the democratisation variables produces mixed results. The partial coefficients for all four (GINC QIG, PIE, PID) primary indices are negative, which is unexpected, but only GINC is significant at 1 per cent. However, with the introduction of the composite index $(D I N)$, the regression produces a negative coefficient that is highly ( 1 per cent) significant, with the adjusted $R^{2}$ improving from 0.85 in the base equation to 0.98 . This shows that while the other individual dimensions of democratisation may not significantly affect current rate of gross domestic savings, the democratic content of power change and the overall rate of improvement in democratisation are negative and significant determinants of current rate of domestic savings.

Table 3.1

Regression of gross domestic savings in nominal terms on the level of democratisation Dependent variable $=$ InGDS; $[\mathrm{N}=27]$

\begin{tabular}{|c|c|c|c|c|c|c|}
\hline \multirow{2}{*}{$\begin{array}{l}\text { Independent } \\
\text { variable }\end{array}$} & \multicolumn{6}{|c|}{ EQUATION } \\
\hline & Base & $\begin{array}{c}\text { Base + } \\
\text { GINC }\end{array}$ & $\begin{array}{c}\text { Base + } \\
\text { QIG }\end{array}$ & $\begin{array}{c}\text { Base }+ \\
\text { PIE }\end{array}$ & $\begin{array}{c}\text { Base + } \\
\text { PID }\end{array}$ & $\begin{array}{c}\text { Base + } \\
\text { DIN }\end{array}$ \\
\hline $\begin{array}{l}\text { IDS } \\
(+)\end{array}$ & $\begin{array}{c}0.264 \\
(0.936)\end{array}$ & $\begin{array}{l}1.446 \\
(8.411)^{1}\end{array}$ & $\begin{array}{c}0.277 \\
(0.923)\end{array}$ & $\begin{array}{c}0.261 \\
(0.906)\end{array}$ & $\begin{array}{c}0.271 \\
(0.897)\end{array}$ & $\begin{array}{c}1.367 \\
(11.685)^{1}\end{array}$ \\
\hline $\begin{array}{r}\text { DSR } \\
(-)\end{array}$ & $\begin{array}{l}-0.389 \\
(4.273)^{1}\end{array}$ & $\begin{array}{l}-0.581 \\
(7.157)^{1}\end{array}$ & $\begin{array}{l}-0.392 \\
(4.154)^{1}\end{array}$ & $\begin{array}{l}-0.400 \\
(4.131)^{1}\end{array}$ & $\begin{array}{l}-0.390 \\
(4.141)^{1}\end{array}$ & $\begin{array}{l}-0.477 \\
(9.221) 1\end{array}$ \\
\hline $\begin{array}{r}\text { RFDI } \\
(-)\end{array}$ & $\begin{array}{l}-0.642 \\
(2.759)^{1}\end{array}$ & $\begin{array}{l}-1.656 \\
(5.586)^{1}\end{array}$ & $\begin{array}{l}-0.644 \\
(2.701)^{1}\end{array}$ & $\begin{array}{l}-0.463 \\
(2.707)^{1}\end{array}$ & $\begin{array}{l}-0.647 \\
(2.620)^{12}\end{array}$ & $\begin{array}{l}-1.200 \\
(7.204)^{1}\end{array}$ \\
\hline $\begin{array}{l}\text { GINC } \\
(+)\end{array}$ & & $\begin{array}{l}-0.249 \\
(2.796)^{1}\end{array}$ & & & & \\
\hline $\begin{array}{l}\text { QIG } \\
(+)\end{array}$ & & & $\begin{array}{c}-0.044 \\
(0.148)\end{array}$ & & & \\
\hline $\begin{array}{l}\text { PIE } \\
(+)\end{array}$ & & & & $\begin{array}{l}-0.112 \\
(0.369)\end{array}$ & & \\
\hline $\begin{array}{l}\text { PID } \\
(+)\end{array}$ & & & & & $\begin{array}{l}-0.024 \\
(0.654)\end{array}$ & \\
\hline $\begin{array}{l}\text { DIN } \\
(+)\end{array}$ & & & & & & $\begin{array}{l}-0.261 \\
(3.141)^{1}\end{array}$ \\
\hline Adjusted $\mathrm{R}^{2}$ & 0.85 & 0.96 & 0.96 & 0.96 & 0.96 & 0.98 \\
\hline F(Prob. F) & $\begin{array}{l}155.7 \\
(000)\end{array}$ & $\begin{array}{c}85.1 \\
(000)\end{array}$ & $\begin{array}{l}119.1 \\
(000)\end{array}$ & $\begin{array}{l}119.8 \\
(000)\end{array}$ & $\begin{array}{l}118.9 \\
(000)\end{array}$ & $\begin{array}{l}263.5 \\
(000)\end{array}$ \\
\hline D W Stat & 1.728 & 1.562 & 1.732 & 1.719 & 1.718 & 1.985 \\
\hline Inv.AR roots & 0.94 & 0.24 & 0.94 & 0.94 & 0.94 & 0.49 \\
\hline
\end{tabular}


Note: Figures in parenthesis are $\mathrm{t}$ statistics. ${ }^{1}$ denotes 1 per cent significance level; ${ }^{12}$ denotes 5 per cent significance level; and ${ }^{13}$ denotes 10 per cent significance level. Sources: extracted from Regressions Output run by author on EVIEWS

In the regressions where real gross domestic savings (RGDS) was used as the dependent variable, the results are different. In the base equation, the coefficients for RFDI and DSR are negative, which is expected, while that for IDS is not. However, only DSR is significant at 5 per cent. In all cases following the introduction of the democratisation variables, the coefficients are positive, which is expected, and in three (GINC, PID and DIN) of the five regressions, the introduction of a democratisation variable results in an improvement in the adjusted $R^{2}$. The coefficients for QIG and PIE are not statistically significant. However, both PID and DIN are significant at 5 per cent and 1 per cent respectively, while GINC narrowly misses the 10 per cent significance level. This shows that democratisation at two dimensional levels - power change and democratic dividends - and at the composite level is a positive determinant of real gross domestic savings.

Table 3.2

Regression of gross domestic savings in real terms on the level of democratisation Dependent variable $=$ InRGDS; $[\mathrm{N}=27]$

\begin{tabular}{|c|c|c|c|c|c|c|}
\hline \multirow{2}{*}{$\begin{array}{l}\text { Independent } \\
\text { variable }\end{array}$} & \multicolumn{6}{|c|}{ E Q U A T I O N } \\
\hline & Base & $\begin{array}{c}\text { Base + } \\
\text { GINC }\end{array}$ & $\begin{array}{c}\text { Base + } \\
\text { QIG }\end{array}$ & $\begin{array}{c}\text { Base }+ \\
\text { PIE }\end{array}$ & $\begin{array}{c}\text { Base + } \\
\text { PID }\end{array}$ & $\begin{array}{c}\text { Base + } \\
\text { DIN }\end{array}$ \\
\hline $\begin{array}{l}\text { IDS } \\
(+)\end{array}$ & $\begin{array}{l}-0.192 \\
(0.887)\end{array}$ & $\begin{array}{l}-231 \\
\quad(1.208)\end{array}$ & $\begin{array}{l}-0.202 \\
(0.955)\end{array}$ & $\begin{array}{c}-0.072 \\
(0.285)\end{array}$ & $\begin{array}{c}-0.051 \\
(0.263)\end{array}$ & $\begin{array}{l}-0.004 \\
(0.021)^{1}\end{array}$ \\
\hline $\begin{array}{l}\text { RFDI } \\
(-)\end{array}$ & $\begin{array}{l}-0.250 \\
(0.953)\end{array}$ & $\begin{array}{c}-0.143 \\
(0.530)\end{array}$ & $\begin{array}{l}-0.276 \\
(1.029)\end{array}$ & $\begin{array}{c}0.336 \\
(0.754)\end{array}$ & $\begin{array}{l}-0.300 \\
(1.238)\end{array}$ & $\begin{array}{c}-0.149 \\
(0.635)\end{array}$ \\
\hline $\begin{array}{l}\text { DSR } \\
(-)\end{array}$ & $\begin{array}{l}-0.193 \\
(2.186)^{12}\end{array}$ & $\begin{array}{l}-0.189 \\
(2.303)^{12}\end{array}$ & $\begin{array}{l}-0.198 \\
(2.242)^{12}\end{array}$ & $\begin{array}{l}-0.416 \\
(4.494)^{1}\end{array}$ & $\begin{array}{l}-0.243 \\
(2.913)^{1}\end{array}$ & $\begin{array}{l}-0.244 \\
(2.959)^{1}\end{array}$ \\
\hline $\begin{array}{l}\text { GINC } \\
(+)\end{array}$ & & $\begin{array}{c}0.005 \\
(1.532)^{13}\end{array}$ & & & & \\
\hline $\begin{array}{l}\text { QIG } \\
(+)\end{array}$ & & & $\begin{array}{c}0.251 \\
(0.782)\end{array}$ & & & \\
\hline $\begin{array}{l}\text { PIE } \\
(+)\end{array}$ & & & & $\begin{array}{l}-0.214 \\
(1.202)\end{array}$ & & \\
\hline $\begin{array}{l}\text { PID } \\
(+)\end{array}$ & & & & & $\begin{array}{l}0595 \\
\quad(2.217)^{12}\end{array}$ & \\
\hline $\begin{array}{l}\text { DIN } \\
(+)\end{array}$ & & & & & & $\begin{array}{c}0.402 \\
(3.208)^{1}\end{array}$ \\
\hline Adjusted $\mathrm{R}^{2}$ & 0.50 & 0.54 & 0.51 & 0.53 & 0.58 & 0.66 \\
\hline F(Prob. F) & $\begin{array}{c}7.6 \\
(000)\end{array}$ & $\begin{array}{c}6.9 \\
(000)\end{array}$ & $\begin{array}{c}6.2 \\
(000)\end{array}$ & $\begin{array}{l}12.8 \\
(000)\end{array}$ & $\begin{array}{c}8.1 \\
(000)\end{array}$ & $\begin{array}{l}10.5 \\
(000)\end{array}$ \\
\hline D W Stat & 1.518 & 1.613 & 1.522 & 1.796 & 1.640 & 1.497 \\
\hline Inv.AR roots & 0.58 & 0.51 & 0.55 & 0.51 & 0.42 & 0.48 \\
\hline
\end{tabular}


Note: Figures in parenthesis are t statistics. ${ }^{1}$ denotes 1 per cent significance level; ${ }^{12}$ denotes 5 per cent significance level; and ${ }^{13}$ denotes 10 per cent significance level. Sources: extracted from Regressions Output run by author on EVIEWS

\section{Domestic investment and level of democratisation}

Domestic lending rate is dropped from the base equation because it was not statistically significant. In one of the two base equations, real gross domestic investment (RGDI) is regressed on change in gross domestic product (CHGDP) and debt service ratio (DSR). Coefficients for both explanatory variables have the expected signs (positive for change in gross domestic product and negative for debt service ratio). The former is significant at 1 per cent while the latter is not. However, DSR is retained because its significance improved in subsequent regressions. Both variables together explain 67 per cent of the variation in real gross domestic investment. The base regression, therefore, confirms that while increases in GDP accelerate investment, debt service payments depress growth of the economy via its negative effect on real investment.

Table 3.3

Nigeria: Regression of nominal gross domestic investment on the level of democratisation. Dependent variable $=\operatorname{lnGDI}[\mathrm{N}=27]$

\begin{tabular}{|c|c|c|c|c|c|c|}
\hline \multirow{2}{*}{$\begin{array}{l}\text { Independent } \\
\text { variable }\end{array}$} & \multicolumn{6}{|c|}{ E Q U A T I O N } \\
\hline & Base & $\begin{array}{c}\text { Base + } \\
\text { GINC }\end{array}$ & $\begin{array}{c}\text { Base+ } \\
\text { Q IG }\end{array}$ & $\begin{array}{c}\text { Base + } \\
\text { PIE }\end{array}$ & $\begin{array}{c}\text { Base + } \\
\text { PID }\end{array}$ & $\begin{array}{c}\text { Base + } \\
\text { DIN }\end{array}$ \\
\hline $\mathrm{CHGDP}$ & 2.800 & 2.860 & 2.850 & 2.910 & 2.840 & 3.530 \\
\hline$(+)$ & $(3.044)^{1}$ & $(3.112)^{1}$ & $(3.133)^{1}$ & $(3.316)^{1}$ & $(3.238)^{1}$ & $(4.511)^{1}$ \\
\hline DSR & -0.184 & -0.168 & -0.171 & -0.133 & -0.173 & -0.169 \\
\hline$(-)$ & $(2.007)^{12}$ & $(1.802)^{13}$ & $(1.868)^{13}$ & $(1.456)$ & $(1.951)^{113}$ & $(2.136)^{12}$ \\
\hline \multirow[t]{2}{*}{$\operatorname{GINC}(+)$} & & 0.084 & & & & \\
\hline & & $(0.978)$ & & & & \\
\hline \multirow[t]{2}{*}{ QIG(+) } & & & 0.339 & & & \\
\hline & & & (1.190) & & & \\
\hline \multirow[t]{2}{*}{$\operatorname{PIE}(+)$} & & & & 0.505 & & \\
\hline & & & & $(1.833)^{13}$ & & \\
\hline \multirow[t]{2}{*}{ PID $(+)$} & & & & & 0.558 & \\
\hline & & & & & $(1.683)^{13}$ & \\
\hline \multirow[t]{2}{*}{$\operatorname{DIN}(+)$} & & & & & & 0.310 \\
\hline & & & & & & $(2.231)^{12}$ \\
\hline Adjusted $\mathrm{R}^{2}$ & 0.84 & 0.95 & 0.95 & 0.95 & 0.95 & 0.96 \\
\hline \multirow[t]{2}{*}{$F($ Prob F) } & 162.1 & 121.5 & 123.9 & 134.9 & 131.1 & 166.6 \\
\hline & $(000)$ & $(000)$ & $(000)$ & $(000)$ & $(000)$ & $(000)$ \\
\hline D W Stat & 1.790 & 1.748 & $1.793)$ & 1.992 & 1.792 & 1.911 \\
\hline $\mathrm{AR}$ roots & 0.93 & 0.95 & 0.95 & 0.94 & 0.96 & 0.99 \\
\hline
\end{tabular}


The coefficient of each of the introduced democratisation variables are positive, which is expected, with two (GINC and QIG) significant at 10 per cent, and three (PIE, PID and DIN) significant at 1 per cent. In all cases following the introduction of a democratisation variable, the adjusted $R^{2}$ improves from 0.67 in the base equation to 0.71 for GINC and QIG, 0.74 for PIE, 0.80 for PID and 0.82 for DIN. This indicates that every dimension of democratisation is positively and significantly related with real domestic investment.
The regression with the rate of current gross domestic investment (GDI) produces a weak relationship between individual dimensions of democratisation and gross domestic investment. Although the coefficients for the four primary democratisation variables (GINC, QIG, PIE and PID) are of the expected (positive) sign, only PIE is significant at 10 per cent. The overall level of democratisation (DIN), however, still shows a positive and significant relationship with current rate of domestic investment.

Table 3.4

Nigeria: Regression of real gross domestic investment on the level of democratisation.

Dependent variable $=\operatorname{lnGDI}[\mathrm{N}=27]$

\begin{tabular}{|c|c|c|c|c|c|c|}
\hline \multirow{2}{*}{$\begin{array}{l}\text { Independent } \\
\text { variable }\end{array}$} & \multicolumn{6}{|c|}{ E Q U A T I O N } \\
\hline & Base & $\begin{array}{c}\text { Base+ } \\
\text { GINC }\end{array}$ & $\begin{array}{c}\text { Base+ } \\
\text { G IG }\end{array}$ & $\begin{array}{c}\text { Base }+ \\
\text { PIE }\end{array}$ & $\begin{array}{c}\text { Base }+ \\
\text { PID }\end{array}$ & $\begin{array}{c}\text { Base + } \\
\text { DIN }\end{array}$ \\
\hline CHGDP & 2.320 & 3.400 & 3.410 & 3.360 & 3.350 & 3.610 \\
\hline$(+)$ & $(4.003)^{1}$ & $(4.201)^{1}$ & $(4.099)^{1}$ & $(4.974)^{1}$ & $(3.962)^{1}$ & $(4.872)^{1}$ \\
\hline DSR & -0.080 & -0.068 & -0.074 & -0.041 & -0.175 & -0.196 \\
\hline$(-)$ & $(1.032)$ & $(0.940)$ & $(1.024)$ & $(0.567)$ & $(2.838)^{1}$ & $(3.673)^{1}$ \\
\hline $\operatorname{GINC}(+)$ & & $\begin{array}{c}0.131 \\
(1.917)^{13}\end{array}$ & & & & \\
\hline $\mathrm{QIG}(+)$ & & & $\begin{array}{c}0.486 \\
(1.839)^{13}\end{array}$ & & & \\
\hline $\operatorname{PIE}(+)$ & & & & $\begin{array}{c}0.597 \\
(2.823)^{1}\end{array}$ & & \\
\hline $\operatorname{PID}(+)$ & & & & & $\begin{array}{c}0.825 \\
(5.636)^{1}\end{array}$ & \\
\hline $\operatorname{DIN}(+)$ & & & & & & $\begin{array}{c}0.300 \\
(3.752)^{1}\end{array}$ \\
\hline Adjusted $\mathrm{R}^{2}$ & 0.67 & 0.71 & 0.71 & 0.74 & 0.80 & 0.82 \\
\hline $\mathrm{F}($ Prob F) & $\begin{array}{l}18.7 \\
(000)\end{array}$ & $\begin{array}{l}16.6 \\
(000)\end{array}$ & $\begin{array}{l}17.0 \\
(000)\end{array}$ & $\begin{array}{l}19.6 \\
(000)\end{array}$ & $\begin{array}{l}27.7 \\
(000)\end{array}$ & $\begin{array}{l}28.5 \\
(000)\end{array}$ \\
\hline D W Stat & 1.375 & 1.817 & 1.114 & 1.498 & 1.409 & 1.695 \\
\hline AR roots & 0.87 & 0.82 & 0.78 & 0.99 & 0.41 & 0.49 \\
\hline
\end{tabular}




\section{Summary of results}

The results outlined above are summarised in Table 6. In general the results show two major findings and one minor finding:

1. In both the dimensional and overall aspects, democratisation appears to be negatively related to gross domestic savings in the short term, but positively related in the long term. However, whether in the long term or in the short term, these relationships appear to be stronger when the overall level of democratisation is considered rather than when democratisation is looked at from its individual dimensions;
2. In both the dimensional and overall aspects, democratisation appears to be positively related to both short-term and long-term gross domestic investment. In terms of the relative strength of these relationships as measured by their levels of significance, the long-term relationships are stronger than their short-term counterparts; and

3. Although isolated and relatively insignificant, political environment (PIE) appears to be negatively related to both short-term and long-term gross domestic saving.

Table 4

Summary of results

\begin{tabular}{|l|l|l|l|l|}
\hline \multicolumn{2}{|l|}{ variable } & \multicolumn{2}{|l|}{ gross domestic saving } & \multicolumn{2}{l|}{ gross domestic investment } \\
\hline & short-term & long-term & short-term & long-term \\
\hline $\begin{array}{l}\text { Power change } \\
\text { (GINC) }\end{array}$ & $\begin{array}{l}\text { negative and } \\
\text { significant 10\% }\end{array}$ & $\begin{array}{l}\text { positive and } \\
\text { significant 14\% }\end{array}$ & $\begin{array}{l}\text { positive but not } \\
\text { significant }\end{array}$ & $\begin{array}{l}\text { positive and } \\
\text { significant 6\% }\end{array}$ \\
\hline $\begin{array}{l}\text { Quality of } \\
\text { governance (QIG) }\end{array}$ & $\begin{array}{l}\text { negative but } \\
\text { not significant }\end{array}$ & $\begin{array}{l}\text { positive but not } \\
\text { significant }\end{array}$ & $\begin{array}{l}\text { positive but not } \\
\text { significant }\end{array}$ & $\begin{array}{l}\text { positive and } \\
\text { significant 7\% }\end{array}$ \\
\hline $\begin{array}{l}\text { Political } \\
\text { environment (PIE) }\end{array}$ & $\begin{array}{l}\text { negative but not } \\
\text { significant }\end{array}$ & $\begin{array}{l}\text { negative but not } \\
\text { significant }\end{array}$ & $\begin{array}{l}\text { positive and } \\
\text { significant } 8 \%\end{array}$ & $\begin{array}{l}\text { positive and } \\
\text { significant 1\% }\end{array}$ \\
\hline $\begin{array}{l}\text { Democratic } \\
\text { dividends (PID) }\end{array}$ & $\begin{array}{l}\text { negative but not } \\
\text { significant }\end{array}$ & $\begin{array}{l}\text { positive and } \\
\text { significant 3\% }\end{array}$ & $\begin{array}{l}\text { positive and } \\
\text { significant 10\% }\end{array}$ & $\begin{array}{l}\text { positive and } \\
\text { significant 1\% }\end{array}$ \\
\hline $\begin{array}{l}\text { Overall } \\
\text { democratisation } \\
\text { (DIN) }\end{array}$ & $\begin{array}{l}\text { negative and } \\
\text { significant 1\% }\end{array}$ & $\begin{array}{l}\text { positive and } \\
\text { significant 1\% }\end{array}$ & $\begin{array}{l}\text { positive and } \\
\text { significant 3\% }\end{array}$ & $\begin{array}{l}\text { positive and } \\
\text { significant 1\% }\end{array}$ \\
\hline
\end{tabular}

\subsection{Discussion}

The discussion of these findings focuses on two key aspects, namely the overall significance of the regressions and the practical implications of the findings for Nigeria. The implications of the findings for the on-going democracydevelopment nexus will form the concluding part of this analysis.

\section{Overall significance of the regressions}

The overall significance of regressions can be judged from the adjusted $R^{2}$, the $F$-statistic and the D-W statistic. The $F$-statistic (and its probability, $p$ ) is the most widely used measure of overall significance of the regression, a test of the collective importance (statistical significance) of the independent variables in the explanation of observed variations in the dependent variable. The adjusted $R^{2}$ is a measure of the goodness of fit of the regression model. Since this measure is by definition adjusted for the number of variables, it may also be used to compare two regressions that have the same dependent variables but a different number of explanatory variables. An added advantage of the adjusted $R^{2}$ for comparative analysis is that it is by definition directly related to $F$. The larger the adjusted $R^{2}$, the greater the $F$ value, and in the limit, when adjusted $R^{2}=1$, the $F$ 
value is infinite; this means that the probability of making an error when 100 per cent of the variations in a dependent variable are ascribed to changes in the included explanatory variables is in fact zero.

Judging by the $F$ value and its probability, the overall significance in both sets of regressions is good. In all cases, the inverted roots of the AR lie within the unit root. Thus, the regressions meet the stationarity condition for an $\mathrm{AR}(1)$ process.

\section{Findings with Nigerian data}

For the period covered by this study, and with Nigerian data, the results of the analysis for gross domestic investment are in line with the optimist viewpoint that democracy fosters economic growth. What requires further discussion is the fact that, contrary to expectations, gross domestic savings has a negative though not significant relation with political environment (PIE). A more democratic political environment is related with lower levels of domestic savings. Although this negative relationship is not transmitted to the overall level of democratisation, the reasons behind the unexpected outcome need to be explored.

Why would savings fall with an improving and rise with a worsening political environment? Against the optimist argument, however, there are a number of possible explanations. First, if private wealth owners feel that the political situation is worsening and might be threatening their fixed assets, they will be motivated to alter their portfolios in favour of more liquid assets in the form of savings deposits. The hope is that, should the political situation become extremely volatile, owners will have quicker access to bank balances than they would to immovable property. Also, in the private sector, poor income earners who feel that their future income stream might be disrupted by politically motivated strikes may postpone some current consumption in favour of savings, particularly for the expected rainy day. Thus in two related ways, one in expectation and the other precautionary, lower levels of democratic political environment may lead to a short-term increase in savings.

These explanations appear to be plausible for Nigeria. The Central Bank of Nigeria
(CBN, 1998: 23-227) reveals that between 1980 and 1984 annual deposits in rural branches of commercial banks in Nigeria averaged N172 million. This was the period when Nigeria enjoyed a relatively peaceful political environment under a democratically elected government. By 1986, following two successive military coups d'état, rural savings had gone up to N873.5 million. Between 1987 and 1989 the average was $\mathrm{N} 2.776$ billion. This rose to N9.470 billion for the period 1990/1991. In 1992, following the election and inauguration of the National Assembly, rural savings dropped to N4.855 billion. One year later, in response to the political crisis that engulfed most urban cities following the annulment of the presidential election, rural savings reached an all-time high of N19.542 billion in 1993. Conversely, real estate in the trading and business sub-sector increased steadily from N129.678 billion in 1979 through N265.625 billion in 1982 to N517.811 billion in 1984. Between 1985 and 1990, real estate stagnated, rising only marginally from N538.146 billion to N589.481 billion. Thus, Nigerians not only moved their assets from fixed to liquid, but also relocated to safer and less politically volatile rural environments.

\section{6}

\section{Conclusion}

It is important to explore the theoretical implications of these findings, in the interests of scientific debate. As would be expected, the findings do not settle the debate in favour of either the optimists or the pessimists. However, they do shed some light on two aspects of the political system-economic growth nexus. First is the dimensional versus the overall effects of democratisation on economic variables, the second is the short-term versus the longterm effects of democratisation on economic variables.

As the results of the analyses show, both dimensional and overall effects of democratisation on the two economic variables are consistent, except for the isolated case of the political environment in long-term gross domestic savings. 
However, the direction of short-term responses in savings decisions to improvements in levels of democratisation differs from that of longrun responses. For example, the results suggest that domestic savings will respond negatively to improving democratisation in the short-term, but positively in the long-term. This appears to be the case with newly democratising polities where governments may be under pressure to increase spending (and decrease savings) in areas such as building democratic institutions and structures to empower the citizenry. In the long-term, when these structures have been put in place, the pressure eases and savings begins to respond positively to improvements in levels of democratisation. This explanation is clearly supported by the fact that the particular dimension of democratisation, democratic dividends, where the bulk of political and economic empowerment resides, appears to be largely responsible for the positive and significant relationship between overall level of democratisation (DIN) and long-term domestic savings (RGDS).

Theoretically, therefore, it can be suggested that the pessimist viewpoint that "democracy leads to increasing demand for welfare spending to the detriment of savings" (Goldsmith, 1995: 158 ) is only a short-term phenomenon.

With respect to domestic investment, the effects of democratisation, whether conceived as dimensional or overall, do not appear to discriminate between short-term and longterm responses. This aspect of the findings strengthens, in part, the optimist theoretical argument that democracy fosters an investment climate and economic growth.

Finally, the strong relationship (as captured in the statistical significance levels) between domestic investment and democratisation and the weak relationship between domestic savings and democratisation further strengthens the initial argument in this study, that we cannot make a general statement regarding the effect of democratisation on economic growth. Future research should aim to identify other economic growth variables and study their individual relationships with democratisation.

\section{Endnotes}

1 The author would like to express his gratitude to the anonymous reviewers for their useful comments on the original manuscript.

2 These include Przeworski, 1966; Huntington and Dominguez, 1975; Marsh, 1979; Landau, 1986; and Sloan and Tedin, 1987. For full references see Sirowy and Inkeles, 1990, pp. 138-145.

3 These include Dick, 1974; Komendi and Meguire, 1985; Pourgerami, 1988, 1992; Scully, 1988, 1992;

Barro, 1989; Remmer, 1990; Bilson, 1982; and Goldsmith, 1995. For full references see Przeworki and Limongi, 1993, pp. 57-64.

4 Every new idea, especially in a controversial and largely subjective field like the measurement of institutional variables, many readers may have difficulty with the new variables adopted in this study. However, access to the original published indices of democratisation for Nigeria may help. See Godson, E. Dinneya, and Asrat Tsegaye, 2004, 'Constructing a cardinal measure of democratisation in a transition polity: the Nigerian example.' Canadian Journal of Political Science. 37(2): 79-106.

5 For detailed arguments for the infeasibility thesis see Robert D Kaplan, 1997. 'Was democracy just a moment?' The Atlantic Monthly, 280(6): 55-80. [Online]. Available at <http://www.theatlantic. com/issues/97dec/democ.htm $>$ [Accessed 9 December 2004]

6 For details of the criteria for choosing the variables and the scoring techniques, see Dinneya and Tsegaye, (2004: 363-367).

7 This section draws heavily on EVIEWS User Guide. EVIEWS is a product of Quantitative Micro Software. The version used here is 3.1. For further details see EVIEWS Help Topics.

\section{References}

1 ADELMAN, I. \& MORRIS, C. (1967) Society, Politics and Development, John Hopkins University Press: Baltimore.

2 AKE, C. (1991) "Rethinking African democracy", Journal of Democracy, 2(1): 32-44.

3 ANDRÉSKI, S. (1968) Military Organization and Society, Stanford University Press; Palo Alto.

4 BOLLEN, K.A. (1993) "Liberal democracy: Validity and method factors in 5 cross-national measures", American Journal of Political Science, 37(4): 1207-1230.

6 CENTRAL BANK OF NIGERIA (1998) Statistical Bulletin, 9(1): 119-210. 
7 DINNEYA, G.E. \& ASRAT, T. (2004)

"Constructing a cardinal measure of democratisation in a transition polity: The Nigerian example", Canadian Journal of Political Science, 37(2): 347-373.

8 FEDDERKE, J.W.; DE KADT, R. \& LUIZ, J. (2001) "Indicators of property rights and political instability in South Africa: 1935-1997", International Review of Law and Economics. 21(1): 103-134.

9 GASTIL, R. (1991) "The comparative survey of freedom: experiences and suggestions", In On Measuring Democracy, Inkeles, A. (ed.) Transactions Publishers.10

11 GOLDSMITH, A.A. (1995) "Democracy, property rights and economic growth", Journal of Development Studies, 32(2): 157-174.

12 HADENIUS, A. (1992) Democracy and Development, Cambridge University Press: Cambridge.

13 IYOHA, M.A. (2000) "An econometric analysis of external debt and economic growth in sub-Saharan Africa." In External Debt and Capital Flight in SubSaharan Africa, Ajayi, S.I. (ed.) IMF: Washington D.C.

14 MBAKU, J.M. (1994) "The political economy of development: An empirical analysis of the effects of the institutional framework on economic development", Studies in Comparative International Development, 29(2): 3-22.
15 PETERSON, D.L. (1994) "Debunking ten myths about democracy in Africa", Washington Quarterly, 17(3): 129-141.

16 PRZEWORSKI, A. \& FERNANDO, L. (1993)

"Political regimes and economic growth", Journal of Economic Perspective, 7(3): 51-69.

17 SKLAR, R. (1986) "Development democracy", Comparative Studies in Society and History, 29(4): 686-714.

18 SKLAR, R. (1987) "Democracy in Africa”, In Political Domination in Africa, Chabal, P. (ed.) Cambridge University Press: Cambridge.

19 SKLAR, R. (1995) "African politics: The next generation", Africa Demos, 3(4): 26-28.

20 SIROWY, L. \& INKELES, A. (1990) "The effect of democracy on economic growth and inequality", Studies in Comparative International Development, 25(1): 126-157.

21 SORENSON, G. (1998.) Democracy and Democratisation: Processes, Prospects in a Changing World: Westview Press: Boulder.

22 TORSTENSSON, J. (1994) "Property rights and economic growth: an empirical study", Kyklos, 47(2): 231-247.

23 VANHANEN, T. (1997) Prospects of Democracy: A Study of 172 Countries. Routledge: London.

24 WEEDE, E. (1983) "The impact of democracy on economic growth”, Kyklos, 36(1): 21-39.26 